\title{
Effects of microwave and heat-moisture treatments on color characteristics, particle size and water distribution of potato starch
}

\section{Chunli Deng ${ }^{1,2}$, Oksana Melnyk ${ }^{1}$, Yanghe Luo ${ }^{2}$}

\author{
1 - Sumy National Agrarian University, Sumy, Ukraine \\ 2 - College of Food and Biological Engineering, Hezhou University, Hezhou, China
}

\section{Keywords:}

Potato starch

Microwave

Heat-moisture

treatment

Color

Particle size

\section{Article history:}

Received

27.09.2021

Received in revised form 17.10.2021

Accepted

30.12.2021

\section{Corresponding author:}

Yanghe Luo

E-mail:

luoyanghe@

tsinghua.org.cn

\section{DOI:}

$10.24263 / 2310-$

1008-2021-9-2-4

\section{Abstract}

Introduction. The purpose of this study is to assess the effect of microwave and heat-moisture treatments on color characteristics, particle size and water distribution of potato starch.

Materials and methods. Native potato starch was modified by microwave and heat-moisture treatments. Such treatments of potato starch were done: single microwave treatment (MW); heat-moisture treatment assisted by microwave pre-treatment (MW-HMT), and heat-moisture treatment assisted by microwave post-treatment (HMT-MW).

Results and discussion. In general, HMT caused a slight increase of lightness ( $\mathrm{L}^{*}$ values), while single MW caused a slight decrease of lightness, indicating that the color of all the HMT treated samples became brighter and the color of the single MW treated sample (MWS) became darker. The color of MW-HMT samples became more reddish, while MWS, HMT and HMT-MW samples became more greenish. Although there were significant differences of the difference of color $(\Delta \mathrm{E})$, it could conclude that all treatments did not markedly change potato starch color for $\Delta \mathrm{E}$ was always below 5. Median diameter (D50), particle diameter of volume $(\mathrm{D}(4,3))$ and particle diameter of surface $(\mathrm{D}(3,2))$ of all treated starch were higher compared with native starch (NS), while the value of specific surface area was significantly decreased by MW and HMT, indicating that these treatments can cause expansion, partial gelatinization and agglomeration of starch granules, resulting in large particle size of starch granules. MW and HMT treatments of potato starch caused the relaxation time $T_{21}$ shifted toward faster relaxation times compared with native starch. Although the water in all starch samples was the main water which at least accounted for $90 \%$, three peaks were observed in relaxation time $\mathrm{T}_{2}$ of MW treated starch (MWS, MW-HMT and HMT-MW), and two peaks were observed in relaxation time $\mathrm{T}_{2}$ of NS and HMT samples, which indicated the MW treated starch had three different state water, while NS and single HMT treated starch only had two different state water. Furthermore, MW and HMT treatments could change the water distribution and improve the interaction between starch and water.

Conclusions. Although MW and HMT treatments did not markedly change potato starch color, these treatments can cause expansion, partial gelatinization and agglomeration of starch granules, resulting in large particle size of starch granules. MW and HMT treatments could change the water distribution and improve the interaction between starch and water. 


\section{Introduction}

Various modification methods have been used to enhance starch properties, including physical (Wang et al., 2018; Colussi et al.,2020), chemical (Ariyantoro et al.,2018) and enzymatic or combined ways (Li et al., 2019). Physical modifications are widely used for starch modification not only because of safety and simplicity, but also because of sustainability and environmental friendliness (Chandrasekaran et al., 2013; Kaur et al., 2012). Microwave treatment is widely used in the food industry at the working frequency of 915 $\mathrm{MHz}$ to $2450 \mathrm{MHz}$ in most part of the world (Hoz et al., 2013). The microwave frequency, system composition, density, temperature and other factors influent the dielectric properties which are crucial indexes to evaluate the ability of food to absorb and transform microwave electromagnetic energy to thermal energy. The dielectric properties of starch-based materials are distinct due to their discrepant compositions, moisture content, metal ion concentration, porosity, and other parameters of a starch-based system ( Tao et al.,2020). Recent researches show that microwave treatment can lead to changes in granule morphology, molecular chain structure and crystalline structure, which consequently affects its functional properties, such as solubility (Singh et al., 2012), swelling capacity (Deka and Sit, 2016), gelatinization (Oyeyinka et al.,2021), retrogradation (Chen et al., 2021) and digestion ability ( Zeng et al., 2016). For example, microwave treatment decreased the swelling power, transparency and thermal properties of millet starch, destroyed the original appearance of the starch granules and formed smaller and lamellar gel blocks (Li et al., 2019). Heat- moisture treatment (HMT) is another commonly used physical treatment that involves the treatment of starch granules at low moisture content $(<35 \%)$ for a certain time period $(15 \mathrm{~min}-16 \mathrm{~h})$ at relatively high temperatures $\left(90{ }^{\circ} \mathrm{C}-120{ }^{\circ} \mathrm{C}\right)$ above glass transition temperature but below the gelatinisation temperature (Li et al., 2020; Chatpapamon et al., 2019). Previous researches show that HMT promotes changes in X-ray diffraction (XRD) patterns, granule morphology, gelatinization properties, swelling power and enzyme digestibility (Chen et al., 2017; Zhou et al., 2020). Moreover, HMT improves the liquefaction of amylose and quality of recrystallization due to molecular chain arrangement inside the starch granule (Jiranuntakul et al., 2011).

Previous studies have reported the impacts of single microwave treatment and single heat-moisture treatment on morphological structural properties, thermal and physicochemical and digestibility of starch (Sui et al., 2015; Zhou et al., 2020). However, few studies exploring the effect of microwave treatment and heat-moisture treatment on the color characteristics, particle size and water distribution of potato starch have been reported.

Therefore, the purpose of this study is to assess the effect of microwave and heatmoisture treatments on color characteristics, particle size and water distribution of potato starch.

\section{Materials and methods}

\section{Materials}

Potato tubers locally known as Favorita cultivar were purchased from a local market in Hezhou city, China. Native starch from potato tubers was extracted with the technology of wet milling extraction as pervious method of Dhritiman Deka and Nandan Sit (Deka and Sit, 2016) and the dried starch was ground and passed through 80 mesh sieve and kept in airtight plastic containers for further analysis. 


\section{Starch samples with single and dual modification}

Heat- moisture treatment. Heat-moisture treatment was performed according to the method of Deng (Deng et al., 2021) with some modifications. 70 g native starch powder (NS) was weighted in $500 \mathrm{~mL}$ Duran laboratory bottle, and ultrapure water was added to adjust moisture content to $25 \%$. After thorough mixing, the glass containers were sealed and equilibrated for 24 hours at $25^{\circ} \mathrm{C}$, samples were then reacted in a hot-air oven (DH411C, Yamato Scientific Co.Ltd., Japan) at $90{ }^{\circ} \mathrm{C}$ for $1.5 \mathrm{~h}, 4 \mathrm{~h}, 8 \mathrm{~h}$ and $12 \mathrm{~h}$ respectively. After heat-moisture treatment, the starch samples were dried in a drying oven at $45^{\circ} \mathrm{C}$ for $24 \mathrm{~h}$ to make sure the moisture content less than $12 \%$. The dried potato starch pulverized for $45 \mathrm{~s}$ using a universal pulverizer, passed through an 80-mesh sieve, vacuum-packed in polyethylene bags, and stored in an airtight container for conducting further studies. The prepared starches were named HMT1.5, HMT4, HMT8 and HMT12.

Microwave treatment. Adjustment of starch moisture content $(25 \%)$ and equilibration were carried out according to the method in Section 2.2.1. Then the starch was placed flat into a petri dish with a diameter of $18 \mathrm{~cm}$, covered with microwave plastic film and evenly pricked 10 holes with toothpicks. The petri dish with starch was exposed in a microwave oven (Galanz, G80F20CN2L-B8(RO), Guangdong Galanz Microwave Appliance Manufacturing Co., LTD, China) to perform the microwave treatment with $400 \mathrm{~W}$ power for 5 min (increasing the power level or time of heating in microwave will cause the starch granules to burn). The treated starch sample was dried and stored as the method in Section 2.2.1. The prepared starches were named MWS.

\section{Dual modification.}

(1) Heat-moisture treatment assisted by pre- treatment of microwave (MW-HMT): The MWS sample was treated with heat-moisture treatment according to the method in Section 2.2.1 to obtain MW-HMT1.5, MW-HMT4, MW-HMT8 and MW-HMT12.

(2) Heat-moisture treatment assisted by poste-treatment of microwave (HMT-MW): HMT samples were treated with microwave according to the method in Section 2.2.2 to acquire HMT1.5-MW, HMT4-MW, HMT8-MW and HMT12-MW.

The treated samples were analyzed for physicochemical, structural and digestive properties. Untreated native potato starch (NS) was used as control.

\section{Color characteristics}

Color measurements of NS and treated starch were carried out using a colorimeter (CR400, Konica Minolta Inc., Japan.) after the calibration of the equipment with a standard-white reflection plate. $L^{*}$ indicates lightness, which varies from black $\left(\mathrm{L}^{*}=0\right)$ to white $\left(\mathrm{L}^{*}=100\right)$, $\mathrm{a}^{*}$ is greenness / redness value, which varies from green $(-60)$ to red $(+60)$ and $\mathrm{b}^{*}$ is blueness/yellowness value, which varies from blue (-60) to yellow $(+60)$. Color difference $(\Delta \mathrm{E})$ between treated starch sample and the native starch (NS) was calculated with the equation:

$$
\begin{gathered}
\Delta \mathrm{E}=\sqrt{\left(\Delta L^{*}\right)^{2}+\left(\Delta \mathrm{a}^{*}\right)^{2}+\left(\Delta \mathrm{b}^{*}\right)^{2}} \\
\Delta \mathrm{L}^{*}=\mathrm{L}^{*}-\mathrm{L}_{0}^{*} \\
\Delta \mathrm{a}^{*}=\mathrm{a}^{*}-\mathrm{a}_{0}{ }^{*} \\
\Delta \mathrm{b}^{*}=\mathrm{b}^{*}-\mathrm{b}_{0}^{*}
\end{gathered}
$$

where $L^{*}, L_{0}^{*}$ is the lightness of treated starch and NS; $a^{*}, a_{0}^{*}$ is the greeness/ redness value of treated starch and NS; $b^{*}, b_{0}^{*}$ is the blueness/yellowness value of treated starch and NS. The smaller value of $\Delta \mathrm{E}$ indicates the smaller color difference between treated starch and NS. 


\section{Particle size distribution}

A laser diffraction particle size analyzer ((BT-2001, Baxter Instruments Co. LTD, China) equipped with a dry dispersion unit was used to determine the particle size distribution of all the starch samples according to the manufacturer's instructions. The starch particle size parameters included particle diameter of volume $(\mathrm{D}(4,3))$, particle diameter of surface $(\mathrm{D}(3,2))$, specific surface area (S.S.A.), D50 represents the corresponding particle size which is smaller than $50 \%$ of the sample particles.

\section{LF-NMR spin- spin relaxation $\left(\mathrm{T}_{2}\right)$ measurements}

Low-field nuclear magnetic resonance (LF-NMR) spin-spin relaxation measurements were carried out using a Niumag Benchtop Pulsed NMR Analyzer (NMI120X, Niumag Electric Corp., Shanghai, China) to determine the water distribution of native and treated starch. A saturated $\mathrm{NaCl}_{2}$ solution was used to equilibrate the water content of the samples for two weeks at $25{ }^{\circ} \mathrm{C}$ until the water activity of the samples $(\mathrm{aw}=0.724)$ was constant and consistent according to the method of Fan (Fan et al., 2013). Approximately $1 \mathrm{~g}$ of equilibrated starch was placed into the NMR tube with diameter of $15 \mathrm{~mm}$ to measure $\mathrm{T}_{2}$ using the Carr-Purcell-Meiboom-Gill (CPMG) sequence. The measurement temperature was $32 \pm 0.1^{\circ} \mathrm{C}$ and the proton resonance frequency was $18.0 \mathrm{MHz}$. Typical pulse parameters were as follows: the time of $90^{\circ}$ plus $\left(\mathrm{P}_{1}\right)$ was $9.5 \mu$ s and the time of $180^{\circ}$ plus $\left(\mathrm{P}_{2}\right)$ was 19.04 $\mu \mathrm{s}$, the waiting time (TW) between subsequent scans was $3500 \mathrm{~ms}$, data from 5000 echoes were acquired as 4 scan repetitions, and each measurement was performed at least 3 times.

\section{Statistical analysis}

All the experiments were conducted in triplicate unless otherwise stated. The Statistical analysis was performed on Data Processing System (version 7.05) and charts were done in Origin Pro 8. Data were analyzed using ANOVA with Duncan's multiple range test, and the values were considered significantly different when $\mathrm{p} \leq 0.05$.

\section{Results and discussion}

\section{Color characteristics}

The color values of the native potato starch (as control) and treated starch were showed in Table 1. In general, HMT caused a slight increase of lightness ( $\mathrm{L}^{*}$ values), while single MW treatment caused a slight, although significant, decrease of lightness, indicating that the color of all the HMT treated samples became brighter and the color of the single MW treated sample (MWS) became darker. The a* values of treated samples varied significantly in different ways depending on the treated ways. Although there was no significant difference of a* values in starch samples with the same treated method, the color of MW- HMT samples became more reddish, while MWS, HMT and HMT-MW samples became more greenish. As can be seen from Table 1, all the treated samples became more yellowish, as significant increase of $b^{*}$ values were obtained for treated samples. Although there were significant differences of the difference of color $(\Delta \mathrm{E})$, it could conclude that all treatments did not markedly change potato starch color from the analysis of $\Delta \mathrm{E}$, given that $\Delta \mathrm{E}$ was always below 5 , indicating that color differences was no visible differentiated of all the treated starch samples (Solaesa et al., 2021; García-Viguera and Zafrilla,2001). 
Color characteristics of native and treated potato starch samples

\begin{tabular}{|c|c|c|c|c|}
\hline San & $\mathbf{L}^{*}$ & $\mathbf{a}^{*}$ & $\mathbf{b}^{*}$ & $\Delta \mathbf{E}$ \\
\hline NS & $99.38 \pm 0.05^{\mathrm{cd}}$ & $4.80 \pm 0.01^{\mathrm{bcd}}$ & $-2.38 \pm 0.01^{\mathrm{i}}$ & - \\
\hline MWS & $98.71 \pm 0.02^{\mathrm{e}}$ & $4.73 \pm 0.03^{\mathrm{g}}$ & $-2.21 \pm 0.03^{\mathrm{h}}$ & $0.70 \pm 0.02^{\mathrm{c}}$ \\
\hline MW-HI & $99.31 \pm 0.24^{\mathrm{d}}$ & $4.81 \pm 0.03^{\mathrm{abc}}$ & $-2.02 \pm 0.06^{\mathrm{f}}$ & $0.42 \pm 0.05^{\mathrm{f}}$ \\
\hline MW-I & $99.46 \pm 0.20^{\mathrm{bcd}}$ & $4.84 \pm 0.02^{\mathrm{a}}$ & $-1.94 \pm 0.05^{\mathrm{e}}$ & $0.48 \pm 0.03^{\mathrm{e}}$ \\
\hline MW-HMT8 & $99.51 \pm 0.20^{\mathrm{abcd}}$ & $4.83 \pm 0.01^{\mathrm{ab}}$ & $-1.71 \pm 0.03^{b c}$ & $0.70 \pm 0.02^{\mathrm{c}}$ \\
\hline MW-HMT12 & $99.54 \pm 0.06^{\mathrm{abcd}}$ & $4.80 \pm 0.03^{\mathrm{abcd}}$ & $-1.60 \pm 0.01^{\mathrm{a}}$ & $0.80 \pm 0.02^{\mathrm{a}}$ \\
\hline HMT1.5 & $99.38 \pm 0.07^{\mathrm{cd}}$ & $4.76 \pm 0.03^{\text {defg }}$ & $-2.15 \pm 0.02^{\mathrm{g}}$ & $0.24 \pm 0.02^{\mathrm{g}}$ \\
\hline HMT4 & $99.59 \pm 0.02^{\mathrm{abc}}$ & $4.77 \pm 0.02^{\text {cdef }}$ & $-2.03 \pm 0.02^{\mathrm{f}}$ & $0.41 \pm 0.01^{\mathrm{f}}$ \\
\hline HMT8 & $99.49 \pm 0.12^{\text {abcd }}$ & $4.78 \pm 0.02^{\text {cde }}$ & $-1.85 \pm 0.01^{\mathrm{d}}$ & $0.55 \pm 0.03^{\mathrm{d}}$ \\
\hline HM & $99.66 \pm 0.08^{\mathrm{ab}}$ & $4.75 \pm 0.04^{\mathrm{efg}}$ & $-1.68 \pm 0.04^{b}$ & $0.76 \pm 0.03^{\mathrm{ab}}$ \\
\hline HMT1.5-MW & $99.70 \pm 0.05^{a}$ & $4.74 \pm 0.01^{\mathrm{fg}}$ & $-2.14 \pm 0.01^{\mathrm{g}}$ & $0.41 \pm 0.03^{\mathrm{f}}$ \\
\hline HMT4-MW & $99.50 \pm 0.05^{\text {abcd }}$ & $4.75 \pm 0.01^{\mathrm{efg}}$ & $-1.85 \pm 0.01^{\mathrm{d}}$ & $0.55 \pm 0.02^{\mathrm{d}}$ \\
\hline HMT8-MW & $99.68 \pm 0.13^{\mathrm{ab}}$ & $4.77 \pm 0.01^{\text {defg }}$ & $-1.89 \pm 0.01^{\mathrm{d}}$ & $0.58 \pm 0.06^{\mathrm{d}}$ \\
\hline HMT12-MW & $99.70 \pm 0.11^{\mathrm{a}}$ & $4.77 \pm 0.03^{\mathrm{def}}$ & $-1.74 \pm 0.02^{c}$ & $0.72 \pm 0.05^{\mathrm{bc}}$ \\
\hline
\end{tabular}

Note: all values are the mean of triplicate determinations \pm SD. The means within the same column with different letters are significantly different $(\mathrm{P}<0.05)$.

\section{Particle size distribution}

The variation of particle size could reflect the changes in agglomeration of the starch before and after modification. The particle size distribution parameters of native and treated potato starch were showed in Table 2 .

Particle size distribution of native and treated potato starch samples

Table 2

\begin{tabular}{|c|c|c|c|c|}
\hline Samples & D50 $(\mu \mathrm{m})$ & $\mathrm{D}(4,3)(\mu \mathrm{m})$ & $D(3,2)(\mu m)$ & S.S.A. $\left(\mathrm{m}^{2} / \mathrm{kg}\right)$ \\
\hline NS & $34.12 \pm 0.40^{c}$ & $36.60 \pm 0.38^{f}$ & $22.24 \pm 0.56^{\mathrm{h}}$ & $99.93 \pm 2.54^{\mathrm{a}}$ \\
\hline MWS & $34.29 \pm 0.16^{\mathrm{bc}}$ & $36.97 \pm 0.07 \mathrm{cdef}$ & $24.06 \pm 0.07^{\mathrm{g}}$ & $92.35 \pm 0.26^{b}$ \\
\hline MW-HMT1.5 & $34.38 \pm 0.09^{\mathrm{bc}}$ & $37.24 \pm 0.21^{\text {bcdef }}$ & $29.67 \pm 0.12^{\text {def }}$ & $74.87 \pm 0.32^{\mathrm{cd}}$ \\
\hline MW-HMT4 & $34.53 \pm 0.03^{\mathrm{abc}}$ & $37.35 \pm 0.08^{\text {abcde }}$ & $30.51 \pm 0.02^{\mathrm{abc}}$ & $72.83 \pm 0.06^{\mathrm{de}}$ \\
\hline MW-HMT8 & $34.91 \pm 0.27^{\mathrm{ab}}$ & $37.79 \pm 0.26^{\mathrm{ab}}$ & $30.88 \pm 0.23 \mathrm{a}$ & $71.96 \pm 0.53^{\mathrm{e}}$ \\
\hline MW-HMT12 & $35.14 \pm 0.68^{a}$ & $37.95 \pm 0.65 a$ & $30.76 \pm 0.56^{\mathrm{ab}}$ & $72.24 \pm 1.31^{\mathrm{e}}$ \\
\hline HMT1.5 & $34.61 \pm 0.28^{\mathrm{abc}}$ & $37.48 \pm 0.19^{\mathrm{abcd}}$ & $30.28 \pm 0.17^{\mathrm{abcd}}$ & $73.38 \pm 0.41^{\text {cde }}$ \\
\hline HMT4 & $34.82 \pm 0.21^{\mathrm{ab}}$ & $37.52 \pm 0.22^{\mathrm{abc}}$ & $29.51 \pm 0.23 \mathrm{ef}$ & $75.29 \pm 0.59^{c}$ \\
\hline HMT8 & $34.73 \pm 0.49^{\mathrm{abc}}$ & $37.33 \pm 0.67^{\text {abcde }}$ & $29.35 \pm 0.25^{\mathrm{f}}$ & $75.71 \pm 0.65^{\mathrm{c}}$ \\
\hline HMT12 & $34.64 \pm 0.23^{\mathrm{abc}}$ & $37.42 \pm 0.17^{\text {abcde }}$ & $29.96 \pm 0.44^{\text {cdef }}$ & $74.18 \pm 1.08^{\mathrm{cde}}$ \\
\hline HMT1.5-MW & $34.36 \pm 0.13^{\mathrm{bc}}$ & $37.03 \pm 0.18^{\text {cdef }}$ & $23.97 \pm 0.42 \mathrm{~g}$ & $92.72 \pm 1.60^{\mathrm{b}}$ \\
\hline HMT4-MW & $34.29 \pm 0.19^{\mathrm{bc}}$ & $37.00 \pm 0.07 \mathrm{cdef}$ & $29.41 \pm 0.24^{\mathrm{ef}}$ & $75.55 \pm 0.62^{\mathrm{c}}$ \\
\hline HMT8-MW & $34.32 \pm 0.11^{\mathrm{bc}}$ & $36.82 \pm 0.09^{\mathrm{def}}$ & $30.11 \pm 0.23^{\text {bcde }}$ & $73.63 \pm 0.84^{\text {cde }}$ \\
\hline HMT12-MW & $34.54 \pm 0.07^{\mathrm{abc}}$ & $36.75 \pm 0.09^{\mathrm{ef}}$ & $30.27 \pm 0.46^{\mathrm{abcd}}$ & $73.41 \pm 1.10^{\text {cde }}$ \\
\hline
\end{tabular}

Notes: all values are the mean of triplicate determinations \pm SD. The means within the same column with different letters are significantly different $(\mathrm{P}<0.05)$. 
The D50, $\mathrm{D}(4,3)$ and $\mathrm{D}(3,2)$ of all treated starch were higher than NS, while the value of S.S.A. was significantly decreased by MW and HMT, which was agreed with precious studies about HMT treated lily starch (Li et al., 2020) MW treated waxy hull-less barley starch (Chen et al., 2021). The reason for the large particle size of MW and HMT modified starch was that the internal temperature of the granules rose rapidly during the MW and HMT treatment, and the internal pressure increased, causing the starch granules to expand, resulting in partial gelatinization and agglomeration of the granules (Li et al., 2020; Chen et al., 2021) .

\section{Relaxation time $\left(T_{2}\right)$ analysis}

In starch-based foods, the physical properties of water can significantly affect the processing quality of starch. LF-NMR technology is the most effective technology for evaluating the distribution and state of water in the starch-water system. Relaxation time $\left(\mathrm{T}_{2}\right)$ is the time required for an excited spin-spin proton to reach dynamic equilibrium after energy exchange with adjacent protons, reflects the difference in the degrees of freedom of water. The less hydrogen protons are bound or higher degree of freedom is associated with longer transverse relaxation time (Han et al., 2009), while the more hydrogen protons are bound or lower degree of freedom corresponds to a shorter transverse relaxation time (Pitombo and Lima, 2003; Luo et al., 2020).

As shown in Figure 1-3 and Table 3, three peaks were observed in $\mathrm{T}_{2}$ of MW treated starch (MWS, MW-HMT and HMT-MW), while two peaks were observed in $\mathrm{T}_{2}$ of NS and HMT samples. The first peak $\mathrm{T}_{21}(0.01-1 \mathrm{~ms})$ corresponded to bound water, which interacted with the surface of amylose and amylopectin chains (Tang et al., 2000).

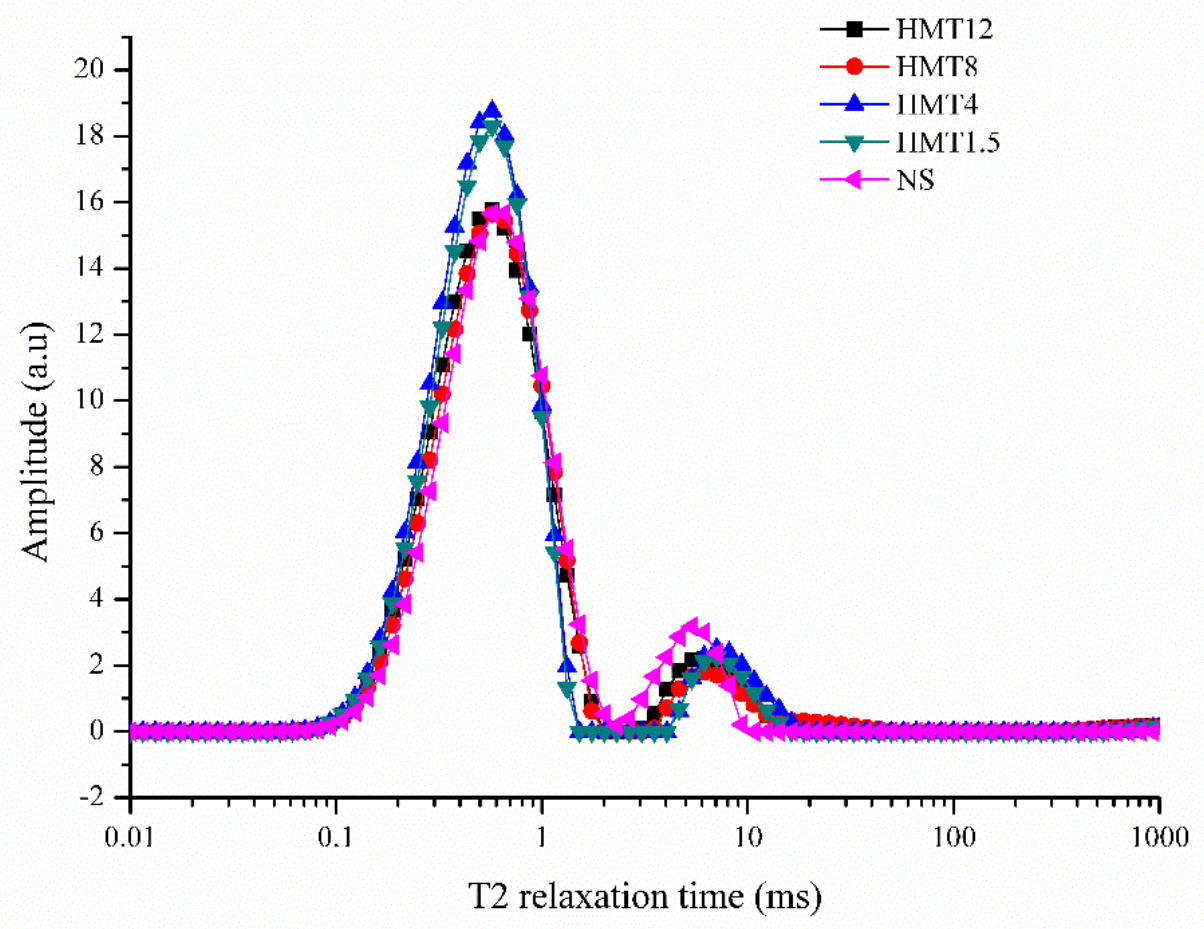

Figure 1. Water distribution in native and single HMT treated starch by LF-NMR 


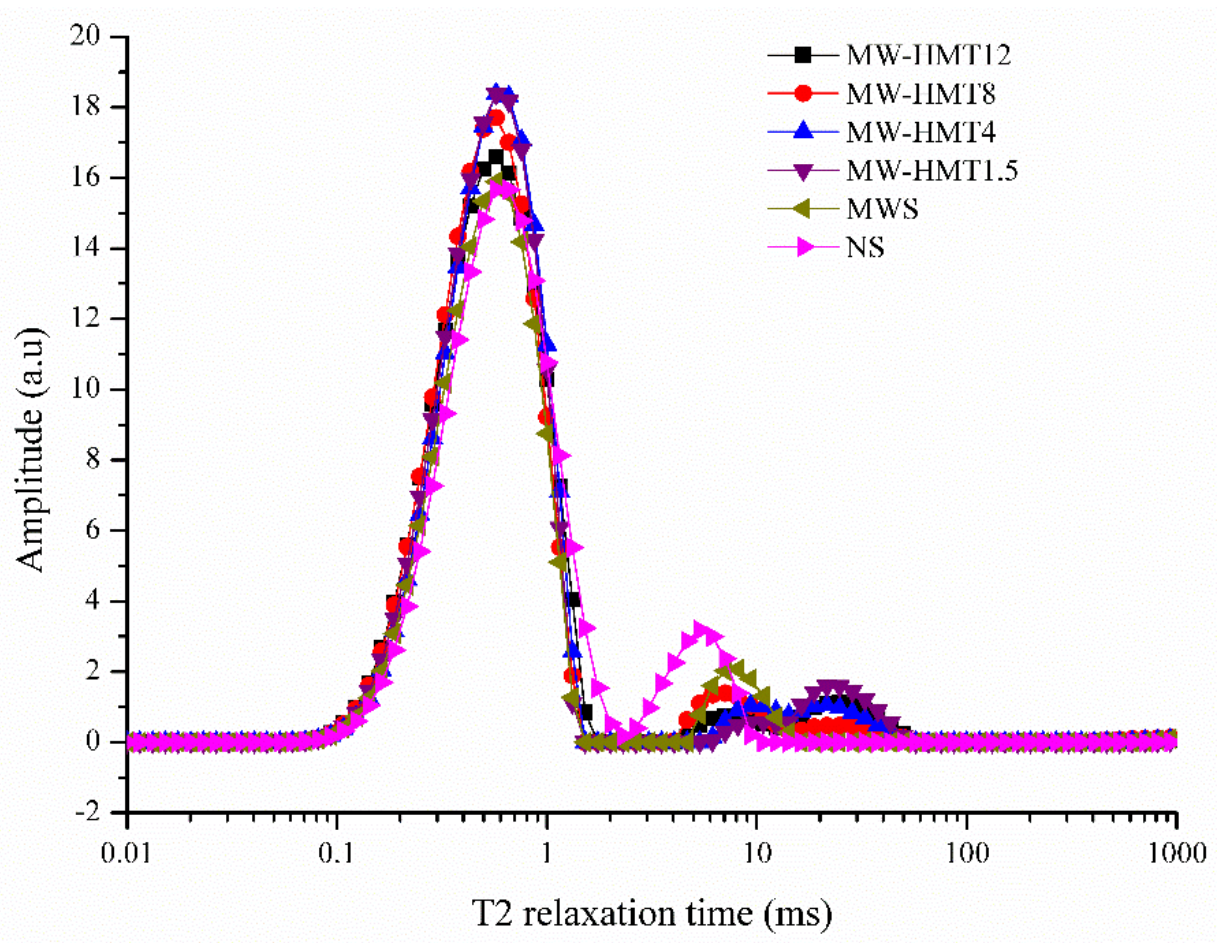

Figure 2. Water distribution in native and MW-HMT treated starch by LF-NMR

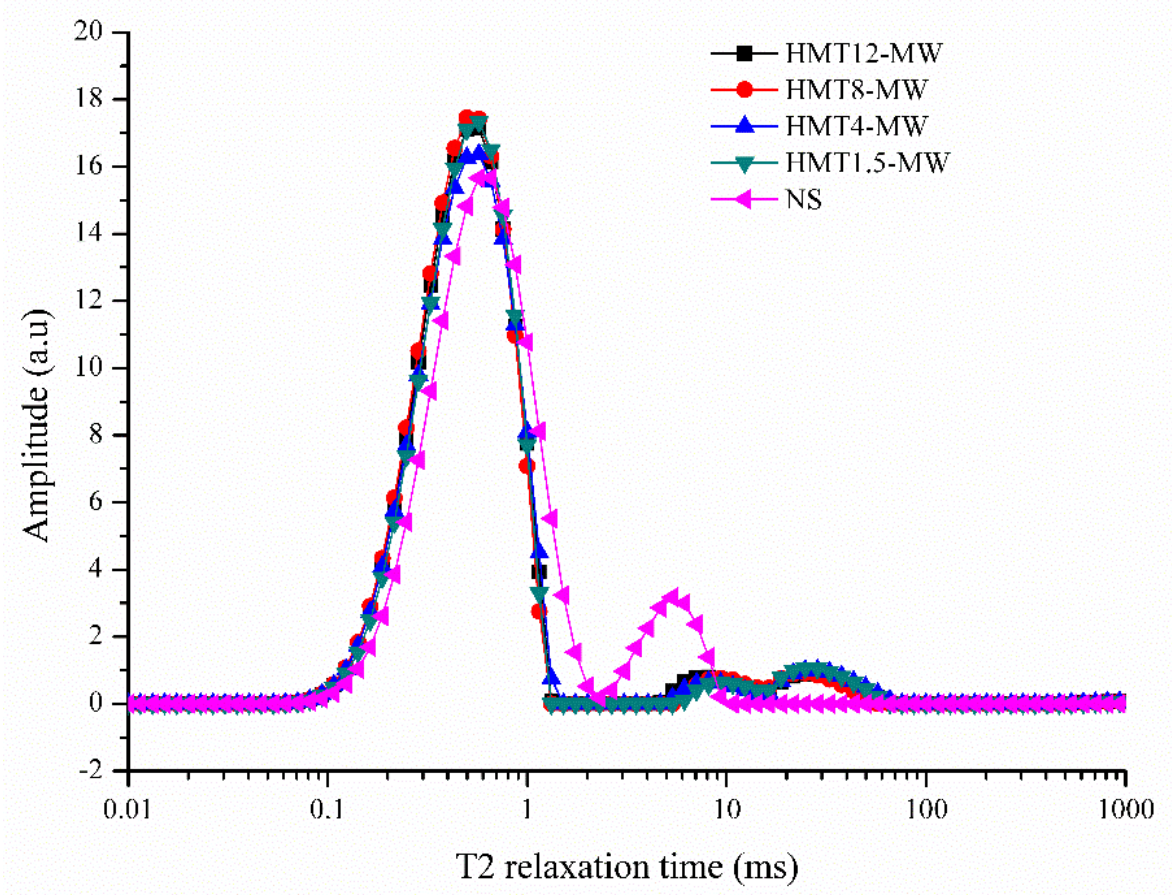

Figure 3. Water distribution in native and HMT-MW treated starch by LF-NMR 
Table 3

Relaxation times $\left(T_{2}\right)$ and corresponding peak areas percentages of water from native and treated starch

\begin{tabular}{|c|c|c|c|c|c|c|}
\hline \multirow[t]{2}{*}{ Samples } & \multicolumn{3}{|c|}{ Relaxation Time (ms) } & \multicolumn{3}{|c|}{ Proportion of water in different state (\%) } \\
\hline & $\mathbf{T}_{21}$ & $\mathbf{T}_{22}$ & $\mathbf{T}_{23}$ & $\mathbf{P T}_{21}$ & PT $_{22}$ & $\mathbf{P T}_{23}$ \\
\hline NS & $\begin{array}{c}0.62 \\
\pm 0.06^{\mathrm{a}}\end{array}$ & $\begin{array}{c}5.74 \\
\pm 0.57^{\mathrm{b}}\end{array}$ & - & $\begin{array}{c}90.48 \\
\pm 0.98^{c}\end{array}$ & $\begin{array}{c}9.52 \\
\pm 0.98^{\mathrm{a}}\end{array}$ & - \\
\hline MWS & $\begin{array}{c}0.59 \\
\pm 0.01^{\mathrm{ab}} \\
\end{array}$ & $\begin{array}{c}8.43 \\
\pm 3.24^{\mathrm{ab}} \\
\end{array}$ & $\begin{array}{c}30.61 \\
\pm 3.02^{\mathrm{a}} \\
\end{array}$ & $\begin{array}{c}92.56 \\
\pm 0.80^{\mathrm{ab}} \\
\end{array}$ & $\begin{array}{c}1.14 \\
\pm 0.06^{\mathrm{e}} \\
\end{array}$ & $\begin{array}{c}6.29 \\
\pm 0.74^{\mathrm{a}} \\
\end{array}$ \\
\hline MW-HMT1.5 & $\begin{array}{c}0.57 \\
\pm 0.00^{\mathrm{ab}} \\
\end{array}$ & $\begin{array}{c}7.73 \\
\pm 2.26^{\mathrm{ab}} \\
\end{array}$ & $\begin{array}{c}25.01 \\
\pm 4.90^{\mathrm{a}} \\
\end{array}$ & $\begin{array}{c}93.06 \\
\pm 0.04^{\mathrm{ab}}\end{array}$ & $\begin{array}{c}1.58 \\
\pm 0.39^{\text {de }}\end{array}$ & $\begin{array}{c}5.36 \\
\pm 0.35^{\mathrm{ab}} \\
\end{array}$ \\
\hline MW-HMT4 & $\begin{array}{c}0.60 \\
\pm 0.05^{\text {ab }} \\
\end{array}$ & $\begin{array}{c}8.52 \\
\pm 0.70^{\mathrm{ab}} \\
\end{array}$ & $\begin{array}{r}24.71 \\
\pm 2.74^{\mathrm{b}} \\
\end{array}$ & $\begin{array}{c}93.39 \\
\pm 0.52^{\mathrm{ab}} \\
\end{array}$ & $\begin{array}{c}3.92 \\
\pm 0.88^{\mathrm{c}} \\
\end{array}$ & $\begin{array}{c}2.69 \\
\pm 0.72^{\mathrm{c}} \\
\end{array}$ \\
\hline MW-HMT8 & $\begin{array}{c}0.57 \\
\pm 0.00^{\mathrm{ab}} \\
\end{array}$ & $\begin{array}{c}7.60 \\
\pm 0.65^{\mathrm{ab}} \\
\end{array}$ & $\begin{array}{l}24.66 \\
\pm 0.16^{\mathrm{a}} \\
\end{array}$ & $\begin{array}{c}93.11 \\
\pm 0.75^{\mathrm{ab}} \\
\end{array}$ & $\begin{array}{c}3.57 \\
\pm 1.42^{\mathrm{c}} \\
\end{array}$ & $\begin{array}{c}3.33 \\
\pm 2.17^{\mathrm{bc}} \\
\end{array}$ \\
\hline MW-HMT12 & $\begin{array}{c}0.57 \\
\pm 0.00^{\mathrm{ab}}\end{array}$ & $\begin{array}{c}8.06 \\
\pm 0.00^{\mathrm{ab}}\end{array}$ & $\begin{array}{c}25.76 \\
\pm 1.40^{\mathrm{a}}\end{array}$ & $\begin{array}{c}93.57 \\
\pm 0.30^{\text {ab }}\end{array}$ & $\begin{array}{c}2.85 \\
\pm 0.64^{\mathrm{cd}}\end{array}$ & $\begin{array}{c}3.57 \\
\pm 0.94 \mathrm{bc}\end{array}$ \\
\hline HMT1.5 & $\begin{array}{c}0.57 \\
\pm 0.00^{\mathrm{ab}}\end{array}$ & $\begin{array}{c}7.10 \\
\pm 0.99^{\mathrm{ab}}\end{array}$ & - & $\begin{array}{c}93.32 \\
\pm 0.18^{\mathrm{ab}}\end{array}$ & $\begin{array}{c}6.68 \\
\pm 0.18^{\mathrm{b}}\end{array}$ & - \\
\hline HMT4 & $\begin{array}{c}0.57 \\
\pm 0.00^{\mathrm{ab}}\end{array}$ & $\begin{array}{c}6.75 \\
\pm 0.53^{\mathrm{ab}}\end{array}$ & - & $\begin{array}{c}92.59 \\
\pm 0.26^{\text {ab }}\end{array}$ & $\begin{array}{c}7.41 \\
\pm 0.26^{\mathrm{b}}\end{array}$ & - \\
\hline HMT8 & $\begin{array}{c}0.57 \\
\pm 0.00^{\mathrm{ab}} \\
\end{array}$ & $\begin{array}{c}6.44 \\
\pm 0.53^{\mathrm{ab}} \\
\end{array}$ & - & $\begin{array}{c}93.31 \\
\pm 1.33^{\mathrm{ab}} \\
\end{array}$ & $\begin{array}{c}6.69 \\
\pm 1.33^{\mathrm{b}} \\
\end{array}$ & - \\
\hline HMT12 & $\begin{array}{c}0.57 \\
\pm 0.00^{\mathrm{ab}}\end{array}$ & $\begin{array}{c}6.60 \\
\pm 0.65^{\mathrm{ab}}\end{array}$ & - & $\begin{array}{c}92.37 \\
\pm 0.94^{\mathrm{b}}\end{array}$ & $\begin{array}{c}7.63 \\
\pm 0.94^{\mathrm{b}}\end{array}$ & - \\
\hline HMT1.5-MW & $\begin{array}{c}0.57 \\
\pm 0.00^{\mathrm{ab}} \\
\end{array}$ & $\begin{array}{c}8.72 \\
\pm 0.86^{\mathrm{a}} \\
\end{array}$ & $\begin{array}{c}24.77 \\
\pm 0.00^{\mathrm{a}} \\
\end{array}$ & $\begin{array}{c}93.61 \\
\pm 0.29^{\mathrm{ab}} \\
\end{array}$ & $\begin{array}{c}2.32 \\
\pm 0.26^{\text {cde }} \\
\end{array}$ & $\begin{array}{c}4.07 \\
\pm 0.04^{\mathrm{abc}} \\
\end{array}$ \\
\hline HMT4-MW & $\begin{array}{c}0.54 \\
\pm 0.05^{\mathrm{b}}\end{array}$ & $\begin{array}{c}8.72 \\
\pm 0.86^{\mathrm{a}}\end{array}$ & $\begin{array}{c}28.61 \\
\pm 0.18^{\mathrm{a}}\end{array}$ & $\begin{array}{c}93.97 \\
\pm 0.53^{\mathrm{a}}\end{array}$ & $\begin{array}{c}2.99 \\
\pm 1.13^{\text {cd }}\end{array}$ & $\begin{array}{c}3.05 \\
\pm 1.666_{b c}\end{array}$ \\
\hline HMT8-MW & $\begin{array}{c}0.54 \\
\pm 0.05^{\mathrm{b}} \\
\end{array}$ & $\begin{array}{c}7.73 \\
\pm 2.26^{\mathrm{ab}} \\
\end{array}$ & $\begin{array}{r}28.76 \\
\pm 5.64^{\mathrm{a}} \\
\end{array}$ & $\begin{array}{c}93.77 \\
\pm 0.88^{\mathrm{ab}} \\
\end{array}$ & $\begin{array}{c}2.52 \\
\pm 0.13^{\text {cde }} \\
\end{array}$ & $\begin{array}{c}3.71 \\
\pm 1.01^{\mathrm{bc}} \\
\end{array}$ \\
\hline HMT12-MW & $\begin{array}{c}0.54 \\
\pm 0.04^{\mathrm{b}}\end{array}$ & $\begin{array}{c}8.52 \\
\pm 0.70^{\mathrm{ab}}\end{array}$ & $\begin{array}{c}27.33 \\
\pm 2.22^{\mathrm{a}}\end{array}$ & $\begin{array}{c}93.77 \\
\pm 0.14^{\text {ab }}\end{array}$ & $\begin{array}{c}3.19 \\
\pm 0.40^{\text {cd }}\end{array}$ & $\begin{array}{c}3.04 \\
\pm 0.41^{\text {bc }}\end{array}$ \\
\hline
\end{tabular}

Notes: all values are the mean of triplicate determinations \pm SD. The means within the same column with different letters are significantly different $(\mathrm{P}<0.05)$. - indicates that there is no value.

It can be seen from Table 3 that the MW and HMT treatments of potato starch caused the $\mathrm{T}_{21}$ shifted toward faster relaxation times compared with native starch (NS), indicating that MW and HMT treatments enhanced the starch-water interaction and self- binding of starch, and consequently resulting in lower mobility of water protons. The second peak $\mathrm{T}_{22}(1-20 \mathrm{~ms})$ corresponded to "semi-crystalline lamellae water" (Tang et al., 2000), which existed in the narrow space between crystals. Due to different spaces, the water in them exhibited different mobilities. Peak of NS was closer to the left than treated starch; they were followed by the single HMT treated starch (HMT1.5, HMT4, HMT8 and HMT12). The peaks $\mathrm{T}_{22}$ of MW treated starch were close to the right and connected with its next peak. The third peak $T_{23}$ was located in $\mathrm{T}_{2}$ between $20 \mathrm{~ms}$ and $100 \mathrm{~ms}$ was attributed to immobilized water, which was regarded as water inside the hexagonal channels of B-type crystal clusters and was defined as "channel water in B-type crystal" by a previous study (Chen et al., 2019). It can be observed from Figure1, the native and HMT treated starch did not have channel water in B-type crystal, while all the MW treated starch contained a certain amount of channel water in B-type crystal. 
The proportion of different state water in native and treated starch were summarized in Table 3. The areas under different component represented the proportion of different state water distribution, namely $\mathrm{PT}_{21}$ (bound water), $\mathrm{PT}_{22}$ (semi-crystalline lamellae water), $\mathrm{PT}_{23}$ (channel water in B-type crystal), respectively. Although the water in all starch samples was the main water which at least accounted for 90\%, the MW treated starch had three different state water, NS and single HMT treated starch only had two different state water. There were significant differences of $\mathrm{PT}_{21}$ and $\mathrm{PT}_{22}$ between NS and all treated starch, NS had the lowest $\mathrm{PT}_{21}$ but highest $\mathrm{PT}_{22}$, indicating MW and HMT treatments could change the water distribution and improve the interaction between starch and water. No significant differences of $\mathrm{PT}_{21}$ were observed between MW treated starch and single HMT treated, but all MW treated starch had lower $\mathrm{PT}_{22}$ than single HMT treated starch; furthermore, all the MW treated starch contained a certain amount of channel water in B-type crystal ( $\left.\mathrm{PT}_{23}\right)$. These results indicated that $\mathrm{MW}$ treatment could result in a certain level of semi-crystalline lamellae water shifting to channel water in B-type crystal.

\section{Conclusions}

In this study, different treated potato starch samples were prepared with MW and HMT methods, and the color characteristics, particle size and water distribution of native and treated potato starch were evaluated by using colorimeter, laser diffraction particle size analyzer and LF-NMR. Although color differences was no visibly differentiated between NS and all treated starch, HMT treatment caused a slight increase of lightness (L* values), while single MW treatment caused a slight decrease of lightness, indicating that the color of all the HMT treated samples (HMT, MW-HMT, HMT-MW) became brighter and the color of the single MW treated sample (MWS) became darker. Although there were significant differences of the differences of color $(\Delta \mathrm{E})$, it could conclude that all treatments did not markedly change potato starch color for $\Delta \mathrm{E}$ was always below 5 , indicating that color difference was no visible differentiated of all the treated starch samples. The results of article size distribution showed that $\mathrm{D} 50, \mathrm{D}(4,3)$ and $\mathrm{D}(3,2)$ of all treated starch were higher than NS, while the value of S.S.A. was significantly decreased by MW and HMT, indicating that MW and HMT treatments can caused expansion, partial gelatinization and agglomeration of starch granules, resulting in large particle size of starch granules. Although the water in all starch samples was the main water which at least accounted for $90 \%$, three peaks were observed in $\mathrm{T}_{2}$ of MW treated starch (MWS, MW-HMT and HMT-MW), two peaks were observed in $\mathrm{T}_{2}$ of native and single HMT treated starch, which indicated the MW treated starch had three different state water, while NS and single HMT treated starch only had two different state water. There were significant differences of $\mathrm{PT}_{21}$ and $\mathrm{PT}_{22}$ between NS and all treated starch, NS had the lowest $\mathrm{PT}_{21}$ but highest $\mathrm{PT}_{22}$, indicating MW and HMT treatments could change the water distribution and improve the interaction between starch and water.

Acknowledgements. The authors gratefully acknowledge the financial support received from the Middle aged and Young Teachers' Basic Ability Promotion Project of Guangxi (Grant No.2021KY0710) and the High-level Innovation Team and Outstanding Scholars Program of Guangxi Colleges and Universities (GJR (2018)

35). The authors are grateful to Guangxi Key Laboratory of Health Care Food Science and Technology for providing laboratory facilities and technical support during this research work. 


\section{References}

Ariyantoro, Achmad, Ridwan, Katsuno, Nakako, Nishizu, Takahisa. (2018), Effects of dual modification with succinylation and annealing on physicochemical, thermal and morphological properties of corn starch, Foods, 7 (133), pp. 1-12.

Chandrasekaran S., Ramanathan S., Basak T. (2013), Microwave food processing-A review, Food Research International, 52(1), pp. 243-261.

Chatpapamon C., Wandee Y., Uttapap D., Puttanlek C., Rungsardthong V. (2019), Pasting properties of cassava starch modified by heat-moisture treatment under acidic and alkaline pH environments, Carbohydrate Polymers, 215, pp. 338-347.

Chen C., Fu W., Chang Q., Zheng B., Zhang Y., Zeng H.. (2019), Moisture distribution model describes the effect of water content on the structural properties of lotus seed resistant starch, Food Chemistry, 286, pp. 449-458.

Chen X., Liu Y., Xu Z., Zhang C., Liu X., Corke H. (2021), Microwave irradiation alters the rheological properties and molecular structure of hull- less barley starch, Food Hydrocolloids, 120(2), pp. 106821.

Chen X., Ma M., Liu X., Xu Z., Zhang C., Sui Z., Corke H.. (2021), Microwave treatment alters the fine molecular structure of waxy hull-less barley starch, International Journal of Biological Macromolecules, 193, pp. 1086-1092.

Chen Y., Xiong X., Gao Q. (2017), Digestibility and physicochemical properties of starchgalactomannan complexes by heat-moisture treatment, Food Hydrocolloids, 77, pp. 853-862.

Colussi R., Kringel D., Kaur L., Zavareze E., Singh J. (2020), Dual Modification of potato starch: effects of heat-moisture and high pressure treatments on starch structure and functionalities, Food Chemistry, 318, pp.126475.

Deka D., N. Sit. (2016), Dual modification of taro starch by microwave and other heat moisture treatments, International Journal of Biological Macromolecules, 92, pp. 416422.

Deng C., Melnyk O., Luo Y. (2021), The effect of heat-moisture treatment conditions on the structure properties and functionalities of potato starch, Potravinarstvo Slovak Journal of Food Sciences, 15, pp. 824-834.

Fan D., Ma W., Wang L., Huang J., Zhang F., Zhao J., Zhang H., Chen W. (2013), Determining the effects of microwave heating on the ordered structures of rice starch by NMR, Carbohydrate Polymers, 92(2), pp. 1395-1401.

García-Viguera C., Zafrilla P. (2001), Changes in Anthocyanins during Food Processing: Influence on Color, ACS Symposium Series, 775, pp. 56-65.

Han M., Zhang Y., Fei Y., Xu X., Zhou G. (2009), Effect of microbial transglutaminase on NMR relaxometry and microstructure of pork myofibrillar protein gel, European Food Research \& Technology, 228, pp. 665-670.

Hoz A.D.L., Loupy D.A. (2013), Microwave frequency effects in organic synthesis. Microwaves in Organic Synthesis, Volume 1, Third Edition.

Jiranuntakul W, Puttanlek C., Rungsardthong V., Puncha-Arnon S., Uttapap D. (2011), Microstructural and physicochemical properties of heat-moisture treated waxy and normal starches, Journal of Food Engineering, 104(2), pp. 246-258.

Kaur B., Ariffin F., Bhat R., Karim A.A. (2012), Progress in starch modification in the last decade, Food Hydrocolloids, 26(2), pp. 398-404.

Li G., Deng Y., Lu L., Zou F., Bo C. (2019), Synergistic effects of branching enzyme and transglucosidase on the modification of potato starch granules, International Journal of Biological Macromolecules, 130, pp. 499-507. 
Li H., Wang R., Liu J., Zhang Q., Li G., Shan Y., Ding S. (2020), Effects of heat-moisture and acid treatments on the structural, physicochemical, and in vitro digestibility properties of lily starch, International journal of biological macromolecules, 148, pp. 956-968.

Li Y., Hu A., Zheng J., Wang X. (2019), Comparative studies on structure and physiochemical changes of millet starch under microwave and ultrasound at the same power, International journal of biological macromolecules, 141, pp. 76-84.

Luo H., Guo C., Lin L., Si Y., Yang W. (2020), Combined Use of rheology, LF-NMR, and MRI for characterizing the gel properties of hairtail surimi with potato starch, Food and Bioprocess Technology, 13(1), pp. 637-647.

Oyeyinka S.A., Akintayo O.A., Adebo O.A., Kayitesi E., Njobeh P.B. (2021), A review on the physicochemical properties of starches modified by microwave alone and in combination with other methods, International Journal of Biological Macromolecules, 176, pp. 87-95.

Pitombo, R. Lima G. (2003), Nuclear magnetic resonance and water activity in measuring the water mobility in Pintado ( Pseudoplatystoma corruscans) fish, Journal of Food Engineering, 58(1), pp. 59-66.

Singh V., Kumar P., Sanghi R. (2012), Use of microwave irradiation in the grafting modification of the polysaccharides-A review, Progress in Polymer Science, 37(2), 340-364.

Solaesa N.G., Villanueva M., Muoz J.M., Ronda F.. (2021), Dry-Heat Treatment vs. HeatMoisture Treatment assisted by microwave radiation: Techno-functional and rheological modifications of rice flour, LWT-Food Science and Technology, 141(2), pp. 110851.

Sui Z., Yao T., Zhao Y., Ye X., Kong X., Ai L. (2015), Effects of heat-moisture treatment reaction conditions on the physicochemical and structural properties of maize starch: Moisture and length of heating, Food chemistry, 173, pp. 1125-1132.

Tang H.R., Godward J., Hills B.P.. (2000), Distribution of water in native starch granules a multinuclear NMR study, Carbohydrate Polymers, 43(4), pp. 375-387.

Tao Y., Yan B., Fan D, Zhang N., Ma S., Wang L., Wu Y., Wang M., Zhao J., Zhang H. (2020), Structural changes of starch subjected to microwave heating: A review from the perspective of dielectric properties, Trends in Food Science \& Technology, 99, pp. 593607.

Wang H., Liu Y., Chen L., Li X., Wang J., Xie F. (2018), Insights into the multi-scale structure and digestibility of heat-moisture treated rice starch, Food Chemistry, 242, pp. 323-329.

Xie H., Gao J., Xiong X., Gao Q. (2018), Effect of heat-moisture treatment on the physicochemical properties and in vitro digestibility of the starch-guar complex of maize starch with varying amylose content, Food Hydrocolloids, 83, pp. 213-221.

Zeng S., Chen B., Zeng H., Guo Z., Lu, X. Zhang Y., Zheng B. (2016), Effect of Microwave Irradiation on the Physicochemical and Digestive Properties of Lotus Seed Starch, Journal of Agricultural and Food Chemistry, 64(12), pp. 2442-2449.

Zhou S., Hong Y., Gu Z., Cheng L., Li C. (2020), Effect of heat-moisture treatment on the in vitro digestibility and physicochemical properties of starch-hydrocolloid complexes, Food Hydrocolloids, pp. 105736. 